IZA DP No. 4495

Citizenship, Co-ethnic Populations and Employment Probabilities of Immigrants in Sweden

Pieter Bevelander

Ravi Pendakur

October 2009 


\title{
Citizenship, Co-ethnic Populations and Employment Probabilities of Immigrants in Sweden
}

\author{
Pieter Bevelander \\ MIM, Malmö University \\ and IZA \\ Ravi Pendakur \\ University of Ottawa
}

\section{Discussion Paper No. 4495 \\ October 2009}

\author{
IZA \\ P.O. Box 7240 \\ 53072 Bonn \\ Germany \\ Phone: +49-228-3894-0 \\ Fax: +49-228-3894-180 \\ E-mail: iza@iza.org
}

\begin{abstract}
Any opinions expressed here are those of the author(s) and not those of IZA. Research published in this series may include views on policy, but the institute itself takes no institutional policy positions.

The Institute for the Study of Labor (IZA) in Bonn is a local and virtual international research center and a place of communication between science, politics and business. IZA is an independent nonprofit organization supported by Deutsche Post Foundation. The center is associated with the University of Bonn and offers a stimulating research environment through its international network, workshops and conferences, data service, project support, research visits and doctoral program. IZA engages in (i) original and internationally competitive research in all fields of labor economics, (ii) development of policy concepts, and (iii) dissemination of research results and concepts to the interested public.
\end{abstract}

IZA Discussion Papers often represent preliminary work and are circulated to encourage discussion. Citation of such a paper should account for its provisional character. A revised version may be available directly from the author. 


\title{
ABSTRACT \\ Citizenship, Co-ethnic Populations and Employment Probabilities of Immigrants in Sweden
}

\begin{abstract}
Over the last decades, Sweden has liberalized its citizenship policy by reducing the required number of years of residency to five for foreign citizens and only two for Nordic citizens. Dual citizenship has been allowed since 2001. During the same period, immigration patterns by country of birth changed substantially, with an increasing number of immigrants arriving from non-western countries. Furthermore, immigrants were settling in larger cities as opposed to smaller towns as was the case before. Interestingly, the employment integration of immigrants has declined gradually, and in 2006 the employment rate for foreign-born individuals is substantially lower compared to the native-born. The aim of this paper is to explore the link between citizenship and employment probabilities for immigrants in Sweden, controlling for a range of demographic, human capital, and municipal characteristics such as city and co-ethnic population size. The information we employ for this analysis consists of register data on the whole population of Sweden held by Statistics Sweden for the year 2006. The basic register, STATIV, includes demographic, socio-economic and immigrant specific information. In this paper we used instrumental variable regression to examine the "clean" impact of citizenship acquisition and the size of the co-immigrant population on the probability of being employed. In contrast to Scott (2008), we find that citizenship acquisition has a positive impact for a number of immigrant groups. This is particularly the case for nonEU/non-North American immigrants. In terms of intake class, refugees appear to experience substantial gains from citizenship acquisition (this is not, however, the case for immigrants entering as family class). We find that the impact of the co-immigrant population is particularly important for immigrants from Asia and Africa. These are also the countries that have the lowest employment rate.
\end{abstract}

JEL Classification: F22, J61, J68

Keywords: immigration, naturalization, citizenship, ethnicity

Corresponding author:

Pieter Bevelander

MIM

Malmö University

20506 Malmö

Sweden

E-mail: pieter.bevelander@mah.se 


\section{Introduction}

Over the last decades, Sweden has liberalized its citizenship policy by reducing the required number of years of residency to five for foreign citizens and only two for Nordic citizens. Dual citizenship has been allowed since 2001. During the same period, immigration patterns by country of birth changed substantially, with an increasing number of immigrants arriving from non-western countries. Furthermore, immigrants were settling in larger cities as opposed to smaller towns as was the case before. Interestingly, the employment integration of immigrants has declined gradually, and in 2006 the employment rate for foreign-born individuals is substantially lower compared to the native-born.

In an era where there is increasing immigration and increasing diversity, and concomitantly a policy era where countries both within and outside Europe are seeking to tighten citizenship acquisition rules, it is important to understand the socio-economic outcomes associated with naturalization. Citizenship acquisition can be viewed as a measure of integration. On the flip side, interaction with co-ethnics, for better or worse, is often viewed as a measure of segregation. Theoretically then, where citizenship acquisition should be correlated with higher employment probabilities in the general labour market, interaction with co-ethnics is correlated with employment in the enclave economy.

The aim of this paper is to explore the link between citizenship and employment probabilities for immigrants in Sweden, controlling for a range of demographic, human capital, and municipal characteristics such as city and co-ethnic population size.

Specifically, we examine the degree to which citizenship acquisition effects employment outcomes, controlling for place of birth, personal characteristics, and the characteristics 
of the city within which immigrants reside. We pay particular attention to the size of the co-immigrant population within a municipality and ask if the size of the community impacts employment opportunities.

Using instrumental variable regressions to control for the impact of citizenship acquisition, we find that age, marital status, and educational level are important determinants of obtaining employment by foreign-born men and women. For immigrants from outside the EU and North America, we find that the size of the co-immigrant population in a city has a significant positive effect on the probability of being employed. In the same way, we find that the acquisition of citizenship makes a real difference to the probability of finding work.obtaining employment. Foreign-born men and women who acquired citizenship are far more likely to be employed than those who have not. The size of the co-ethnic population has a positive impact for many immigrant groups-as the coethnic population increases, the probability of being employed also increases. It appears to be particularly important for immigrants from Asia and Africa, who are also the immigrants that face the lowest employment prospects.

\section{Immigration, Citizenship and Employment Immigration and employment integration}

Post-war immigration to Sweden came about in two waves. In the 1940s, 50s and 60s, labour immigration from the Nordic and other European countries was a response to excess demand for labour due to the rapid industrial and economic growth of that time. Organized recruitment of foreign labour and a general liberalisation of immigration policy facilitated migratory moves to Sweden. The lower rate of economic growth and increased unemployment in the early 1970s diminished the demand for foreign labour. As 
a consequence, migration policy became harsher (Castles and Miller 2003). Labour immigration from non-Nordic countries ceased in the 1970s while the number of labour immigrants from other Nordic countries decreased gradually. Since the early 1970s, refugees and tied-movers have dominated the migration inflow, coming primarily from Eastern Europe and non-European parts of the world.

Labour migration to Sweden was primarily from the Nordic countries, but also from other Western European countries (1950s) and the Balkans (1960s) (Lundh and Ohlsson 1999). These labour migrants typically had no difficulties in finding employment and settling down in Sweden with their families. According to earlier studies (Wadensjö 1973; Ohlsson 1975), foreign-born men and women had higher employment rates than natives in 1970. A gradual decrease in the employment rate of foreign-born men is noticeable from the 1970s and onwards. For foreign-born women, we see an increase in employment up to the middle of the 1980s, but this increase is not in parity with the increase in employment of native women. Both the native- and foreign-born were negatively affected by the economic crisis of the early 1990s, but the relative decline of the immigrant employment rate was larger. [AUTHOR: you could replace "natives and the foreign-born" throughout with "the native- and foreign-born" if you wish to avoid any confusion between "native-born” and indigenous peoples. You'd need to do a search through the entire paper for "native" if you decided on this option.] The employment gap between natives and the foreign-born has narrowed since the middle of the 1990s. The lower employment integration of immigrants who arrived in the 1970s caused the average immigrant employment rate to decrease in the 1990s and early 2000s (Bevelander 2000). 
A snapshot of today's employment integration by country of birth shows us that almost all foreign-born groups, and in particular newly arrived groups of refugees, have lower employment rates than natives. The general pattern is that natives have the highest employment rate, followed by Europeans and thereafter non-Europeans (Bevelander 2009).

Different studies have put forward explanations as to why the employment rate among immigrants in Sweden is lower than that for natives. In addition to educational level differences, language barriers, and economic restructuring, a larger influx of refugees than in earlier decades together with various types of discrimination are found to be partially responsible for the gap in employment rates between various groups of immigrants relative to natives.

\section{Ethnic Enclaves}

In the context of labour markets, cultural communities may be closely connected to labour market enclaves for three reasons (see Bonacich and Modell 1980; Wilson and Portes 1980). First, labour market enclaves may offer a degree of social comfort through language and shared identity that is not available outside the enclave. Second, ethnically defined enclaves may buffer the effects of ethnically based discrimination on the part of mainstream society. Third, Breton (1974) introduces the concept of “institutional completeness,” which in part describes the variety of services available within an ethnic or cultural enclave. Enclaves that are institutionally complete offer a wide variety of services and employment opportunities to group members. Large enclaves are more likely to be institutionally complete than small enclaves. We may then expect workers in large enclaves to earn more than workers in small enclaves because of the greater degree 
of choice that exists. Pendakur and Pendakur (2002) assessed the labour market impact of three types of enclaves in Canada (ethnic, linguistic, and ethno-linguistic) and concluded that the size of the ethnic enclave is important in reducing earnings differentials across minority groups.

\section{Citizenship and employment}

Although political and research interest in the topic has grown in recent years, there is no overwhelming number of studies analyzing the socio-economic impacts of the citizenship ascension of immigrants. Internationally, it was Chiswick (1978) who did the first study tracing the economic performance of immigrants to the US, including consideration of whether immigrants had become US citizens or not. Initially this study finds a positive effect of naturalization on earnings. When including years since migration, however, this initial effect of citizenship acquisition becomes insignificant.

Renewed interest in the socioeconomic effects of naturalization can be observed in both North America and several European countries. Bratsberg et al. (2002), employing both cross-sectional and longitudinal data for the US, shows a positive significant effect of naturalization on the earnings growth of immigrants, controlling for differences in unobserved individual characteristics. Using cross-sectional data, DeVoretz and Pivnenko (2006, 2008) show for Canada that naturalized immigrants had higher earnings and consequently made larger contributions to the Canadian federal treasury than their non-naturalized counterparts. Similarly, Akbari (2008) used cross-sectional data for the year 2000 in the US and found that naturalized immigrants have increased treasury payments as well as a higher rate of welfare participation.In addition, tax payments exceed transfer payments for naturalized immigrants after ten years of 
residence in the US. Mazzolari (2007) found employment and earnings increased for naturalized Latin American immigrants to the US when their home countries passed dual citizenship laws and granted expatriates the right to naturalize in the receiving country.

For Europe, Kogan (2003) analyzed the impact of naturalization policy on former Yugoslavian immigrants to Sweden and Austria and showed a positive effect of naturalization for Austria but not for Sweden, indicating that the institutional framework around citizenship is different in the two countries, consequently impacting the effects of naturalization. Bevelander and Veenman (2006) analyzed the naturalization effect on Turkish and Moroccan immigrants to the Netherlands with cross-sectional survey data. The results of the multivariate analyses indicate that naturalization of Turks and Moroccans in the Netherlands is not positively related to cultural integration or to employment integration. In their 2008 study, Bevelander and Veenman analyze the effect of naturalization on refugee groups in the Netherlands and find naturalization to have a positive effect on the probability of obtaining employment. Moreover, this analysis indicates that so-called "naturalization classes" have no significant effect on the labour market participation of immigrants. For Norway, using longitudinal data, Hayfron (2008), shows that refugees in particular have higher earnings when naturalized relative to nonnaturalized immigrants and confirms that naturalization is positively related to economic integration. Similarly, in a study of Germany using panel data, Steinhardt (2008) finds an immediate positive naturalization effect on wages as well as an accelerated wage growth in the years after the naturalization.

Using 1990 census data for Sweden, Bevelander (2000) shows a log odds increase of obtaining employment for those naturalized compared to non-naturalized. Scott 
(2008), however, using longitudinal data for a number of immigrant countries, found only small “naturalization” effects on income. Moreover, Scott’s study suggests that this citizenship effect is largely a selection effect and not a function of citizenship itself.

Summarizing the literature on citizenship and economic integration, and in line with Bevelander and DeVoretz (2008), studies for the US and Canada seem to support the existence of a "citizenship premium" whereas European studies show only scattered support for this hypothesis. One reason for the difference in results may be the variance in data across countres. Another may be that citizenship effects could be mixed with other selection effects, as well as issues of participation.

\section{Citizenship in Sweden}

Citizenship in Sweden is based on the jus sanguinis principle. Even if they are born in Sweden, the children of non-Swedish citizens are not automatically entitled to Swedish citizenship. Naturalisation is possible after five years, and for refugees, after four years, of residence in Sweden. Citizens from other Nordic countries are exceptions to this rule and can obtain citizenship after two years of residence. In addition, the applicant has to be eighteen years of age or older and have no criminal record. ${ }^{2}$ Acquiring citizenship by notification is also possible. This is basically a simplified juridical naturalisation procedure that is mainly used by Nordic citizens. For notification, the applicant must meet the following requirements: eighteen years of age or older, five years of residence in Sweden, and no prison sentencing during this time.

Citizenship legislation has been reformed over the past forty years, with respect to naturalisation, civil and political rights of citizens and non-citizens, as well as dual

\footnotetext{
${ }^{2}$ In this case, the applicant has a waiting period before he or she can apply for Swedish citizenship.
} 
citizenship. These changes have also led to debates about the meaning of citizenship.

Sweden has, perhaps, the most liberal naturalisation rules in Europe. The waiting period for citizenship was shortened in 1976, and the subsistence requirement, ${ }^{3}$ which had been relaxed during the 1950s and 1960s, abolished, as was the language proficiency test. Despite a number of debates and proposals—most recently during the 2002 electoral campaign—about naturalisation requirements, including language proficiency, no changes to legislation or policy have been made. Compared to other European countries, the issue has been less debated in Sweden.

Naturalisation rates vary among persons of different nationalities (Table 1). Whereas most people from south-eastern Europe, the Middle East, and Africa naturalise, fewer do so from the Nordic countries and north-western Europe, with the exception of Finland and Germany.

The relation between residence and citizenship is also important. Most of the rights given to citizens are also granted to others residing in the country, with some exceptions such as the exclusive right to enter the country and voting rights in national elections. As well, legally speaking, it is easier to limit certain civil rights when it comes to foreigners. The citizenship requirement for several government positions has been relaxed over time and today only a few positions-including certain senior officials, judges and military personnel—are reserved for citizens. ${ }^{4}$

Following the increasing international emphasis on social equality, changes were made in the late 1960s to minimise the differences between citizens and non-citizens

\footnotetext{
${ }^{3}$ The subsistence requirement relates to persons' ability to support themselves in terms of work or other income.

${ }^{4}$ Obtaining a Swedish passport reduces barriers in certain jobs, such as those in the transport sector or cross-border service jobs.
} 
regarding access to welfare arrangements and social rights. This near-equal status within these contexts has by and large remained the case. Occasionally, debates do take place, for instance about regulating labour migration from the new member states in the EU 2004. Proponents of regulation argued that Swedish welfare systems are vulnerable to immigration because of the connection between residence and social rights. Their opponents maintained that Sweden has one of the strictest systems in Europe regarding access to social rights for irregular migrants. Adult irregular migrants have access only to emergency hospital care and the access to education for minors was not guaranteed for a long time. With increasing numbers of irregular migrants in Sweden, this has recently become a topic of intense debate.

A central change during the mid 1970s was to grant voting rights in local and regional elections to permanently residing non-citizens. The bill was adopted unanimously by parliament in 1975 and applied for the first time in the 1976 election. At the time, there were high expectations that this would lead to extensive participation in elections, but as discussed below, voter turnout has actually dropped over the past thirty years. Extending non-citizens' voting rights to national elections was discussed in the late 1970s and early 1980s. The Social Democrats and the Communists favoured this, arguing that voting rights should be tied to residence, whereas the Centre-Right parties argued against the proposal, maintaining that citizenship and voting rights are intrinsically tied together.

The debate about voting rights affected the discussion of dual citizenship. An extensive de facto toleration of dual citizenship evolved in the late 1970s. Authorities exempted persons from renouncing their existing citizenship when becoming a Swedish 
citizen in cases when it was impossible to renounce the existing citizenship, or very difficult and costly to do so. Despite some debates, no changes were made to dual citizenship legislation in the 80s. When the issue reappeared in the late 1990s, all parties except the Moderate Party came to accept that dual citizenship should be allowed and the legislation was changed in $2001 .^{5}$

These changes to citizenship legislation and practice have involved debates about the meaning of citizenship. Opponents to the changes have often remarked that citizenship is devalued by these changes and that the active stance on the part of persons wanting to become citizens should be emphasised. The latter argument is found in the debates about national voting rights, dual citizenship, and in the recent discussions about naturalisation requirements. Proponents have placed weight on naturalisation's positive effects for immigrants’ social, economic and political integration. That persons permanently residing in the country should have the opportunity to express their political views on matters of public concern has often been emphasised, as well as the more recent argument that in today's globalised world, people feel at home in several places, and this does not weaken their ties to any one place. Opponents have stressed that notwithstanding such changes, it is of central importance that persons make a choice about the political community to which they belong.

\section{Data, method and model}

Our data are drawn from the 2006 Swedish register through STATIV, the statistical integration database held by Statistics Sweden. These data contain information

\footnotetext{
${ }^{5}$ The Centre-Right parties, which had opposed dual citizenship in the 80s, changed their position in the 90s, partly due to the de facto toleration, and partly because of an increasing focus on Swedish citizens wanting to become citizens in other countries while retaining their bonds with Sweden.
} 
for every legal Swedish resident, including age, sex, marital status, children in the household, educational level, employment status, country of birth, years since migration, ${ }^{6}$ and citizenship status. The sample we employ in the analysis is the population aged 2564. The lower-age boundary was chosen mainly because of the presumption that individuals older than 24 have finished their studies and are likely to be active in the labour market. The upper-age demarcation was chosen because many individuals leave the labour market at this age.

We limit our sample to immigrants who have the potential to be active in the labour force. This is true for all Nordic and EU-25 immigrants on entry. However, nearly all non-Nordic/non-EU immigrants spend the first few years of residence in settlement training courses and therefore have limited possibilities to acquire gainful employment. ${ }^{7}$ For this reason, we only include non-Nordic/non-EU immigrants who have been resident in Sweden for at least two years.

Our study has two main goals. First we wish to understand how citizenship acquisition may be a factor in attaining employment. Second we wish to understand the degree to which the presence of an ethnic enclave may contribute to patterns of employment across different immigrant groups. In order to do so, we run two types of regressions. First we run normal OLS regressions for all immigrants who are eligible to work where the dependent variable is whether or not the respondent is employed. Second we "instrument" citizenship and run a similar set of regressions as well as a set of regressions that break out place of birth and immigrant intake class. In IV regressions

\footnotetext{
${ }^{6}$ Since Statistics Sweden has no individual information on year of immigration before 1968, we exclude immigrants arriving before that date from the analysis.

${ }^{7}$ This is largely true for immigrants from North America as well, and we therefore treat these immigrants as eligible for employment on entry.
} 
focussed on place of birth, we include a variable that describes the size of the co-ethnic population. In this way we can see the impact of the size of the ethnic enclave in a given city on the employment prospects of co-ethnic members. In both sets of regressions, we include contextual information on the municipality of residence.

We understand both citizenship acquisition and working to be a form of participation in the larger society. Within this context, the impact of citizenship may be interpreted two ways: Citizenship acquisition may be a sign of commitment to Sweden, in that immigrants who acquire citizenship may be signalling their intentions to remain and participate in Swedish society; and,within the context of employment, citizenship acquisition may act as a signal to employers that the prospective employee is committed to remaining in Sweden and is thus a better "risk." We instrument citizenship because we believe that citizenship acquisition is wrapped up with a host of other participatory factors, including whether or not a person is employed. If this is the case, people who get a job are also likely to become citizens. In order to remove the bias caused by both actions being forms of participation, we use citizenship acquisition rules and the years since first eligibility for citizenship as an instrument for citizenship. The rules are as follows:

1. Immigrants from Nordic countries who have lived in Sweden for two or more years are eligible for citizenship. For Nordic immigrants, the number of years in Sweden after two years of residence is assumed to be the number of years he or she has been eligible for citizenship. 
2. Immigrants from other countries are eligible to apply for citizenship after five years. The number of years after this is considered to be the number of years he or she has been eligible for citizenship.

By "instrumenting" citizenship in this way, we interpret the coefficient for citizenship as the "clean" effect of citizenship on employment possibilities (without the impact of participation that is correlated with getting a job).

We run a similar set of regressions by intake class. This allows us to examine the degree to which citizenship acquisition may differentially impact family and refugee classes of intake. We also run separate instrumental variable regressions for each of the ninecountries of birth groups. This is equivalent to a model in which all variables are interacted with country of birth. Within these regressions, we include a variable that identifies the number of people in the municipality who share place of birth with the respondent.

We include fourteen variable types in our models. Contextual variables, drawn from the registry, include the log of the city population, the log of the immigrant population, and the local unemployment rate for the city labour market area. In order to define the size of the enclave population, we aggregated immigrant place of birth data from the Swedish registry to a municipal level and then merged this new dataset with our individual level dataset.

Demographic variables include age (four dummy variables), marital status (four dummy variables), presence of children in the household (four dummy variables), and a dummy variable indicating whether the spouse is Swedish. 
Socio-economic variables include schooling (five dummy variables) and schooling interacted with whether the last level of schooling was outside Sweden (for a total of ten dummy variables). For regressions with all immigrants, we include country of origin (nine dummy variables), years since immigrating, and citizenship. ${ }^{8}$

\section{Results}

\section{Descriptives}

Table 2 provides information on the percent of men and women who are employed by country of birth and citizenship status. The most important thing to note in this table is the substantial variance in employment probabilities across groups and citizenship. Over four-fifths of Swedish-born men and women are employed. Looking first at citizens, we see that amongst female immigrants, the employment rate ranges from a high of 72 percent for East Asian women to a low of 48 percent for women from the Middle East. For women who are not Swedish citizens, the employment rates are considerably lower for most groups compared to their co-ethnics who are citizens. Among men with citizenship, over 70 percent of those from the Nordic countries, East Asia, and the Americas are employed. Around 70 percent of immigrant citizens from the EU and the rest of Europe as well men from South Asia are employed. However, for other groups, that proportion drops to about 60 percent. As was the case for women, men who are citizens are more likely to be employed than their co-ethnic non-citizens.

Our examination of some fairly basic descriptives suggests that citizenship acquisition is correlated with higher employment integration in the Swedish labour

\footnotetext{
${ }^{8}$ We use the EU 25 definition for our EU (non-Nordic category).
} 
market. Our question is whether citizenship still has this impact when controlling for other variables and whether the size of the enclave acts to increase the employment rate.

\section{Regressions}

\section{OLS Regression Results:}

Table 3 shows results from two regressions (split by sex) where the dependent variable is whether the respondent is employed. In this table, the sample only includes immigrants. Looking first at the contextual variables, for both men and women, we can see that as city size increases, the probability of being employed decreases. However, as the number of immigrants and the employment rate in a city increases, the probability of having a job increases.

Looking at personal characteristics, we see that women age 35-44 are more likely to be employed than younger or older women. As compared to being single or married, being separated or widowed results in lower probabilities of being employed (coefficients range from -0.02 to -0.04 ) but having a Swedish spouse is correlated with higher probabilities of having a job (0.07). Generally, higher levels of schooling are correlated with higher probabilities of being employed. Indeed, coefficients for being in the upper level of schooling are over twice that of being in the lower level ( 0.31 compared to 0.15 ). The place of schooling variable identifies whether a respondent obtained the last level of schooling from outside Sweden. It is insignificant, but interacting place of schooling with level of schooling has a small negative impact (ranging from no significant impact for lower secondary to -0.03 for upper university).

As compared to immigrants from Nordic countries, women from all other countries have lower probabilities of employment with coefficients ranging from -0.07 
for women from Latin America to -0.23 for women from the Middle East. The impact of citizenship acquisition is not terrible strong (0.06).

Looking at men, we see that aging is correlated with lower probabilities of being employed. Men who are married have a higher probability of being employed than other marital status categories (single, divorced or separated). The impact of Swedish schooling is somewhat weaker for men as compared to women, with coefficients ranging from 0.10 at the low end of the education spectrum to 0.21 at the upper end. However the impact of foreign schooling is different. Obtaining schooling from outside Sweden results in slightly higher probabilities of being employed. For example, obtaining a lower secondary or a university certificate from outside Sweden results in a coefficient of +0.03 (0.05 obtaining the last level of schooling outside Sweden plus -0.02 for having a lower secondary or university certificate).

As was seen for women, compared to immigrant men from Nordic countries, men from other countries all have lower probabilities of employment. However, it should be noted that the effects tend to be lower than those seen for women. As compared to immigrants from Nordic countries, men from the EU are slightly less likely to be employed (coefficient of -0.02). The coefficient for men from the Middle East is -0.16 .

For both men and women, years since migration and citizenship status are important determinants of employment. The coefficient for years since migration is 0.02 for women and 0.01 for men.

IV Regressions: (H3)

Table 4 shows results that are similar in spirit to those seen in Table 3. However the regression results from this table instrument citizenship to be a product of eligibility 
and years since being eligible. This allows us to examine the degree to which effects attributed to socio-economic characteristics (in Table 3) are actually a product of citizenship acquisition.

Comparing coefficients across the two tables, we see that the impacts of city characteristics are basically the same. This is also true for the socio-demographic characteristics (age, marital status, presence of children and schooling).

The coefficients for our "clean” version of citizenship is 0.42 for women and 0.22 for men, suggesting that citizenship has a very strong impact on the probability of getting a job. Further, there are important differences that become evident by considering place of birth. [AUTHOR: please make sure this conveys your intended meaning. Reword as needed.]Instrumenting citizenship dramatically increases the negative impact of being born outside the Nordic countries. For example, amongst women, instrumenting citizenship often doubles the negative impact of being an immigrant—in Table 3, for instance, the coefficient for women born in the EU is -0.08 , while in Table 4 it is -0.16 . For women from the Middle East, the coefficient is -0.23 in Table 3 and -0.43 in Table 4 . Among men, the impact of instrumenting citizenship is strong but not quite as stark. The coefficient for men from the Middle East is -0.16 in Table 3 and -0.23 in Table 4.

\section{Differences by Class:}

Table 5 shows partial regression results from regressions modelling the probability of being employed for all immigrants, family class and refugee class immigrants. Results for all immigrants are shown for ease of comparison since they are also available in Table 3. The key point to draw from Table 4 is that citizenship is far more important for independent and refugee class immigrant women than for family class 
immigrant women. The citizenship coefficient for family class women is insignificant while it is positive and strong for all immigrants and refugees (0.42 and 0.16 respectively). For men the differences are starker. The coefficient for family class males is -0.20 while for other immigrants it is strong and positive. This suggests that family class immigrants are not coming to Sweden for purposes of work, and that therefore citizenship acquisition does not have a significant impact.

\section{Differences by country of birth:}

Tables 3 and 4 provide a bird's eye view of the impact different characteristics have on the probability of employment. These tables allow us to understand the average degree to which the probability of employment differs across immigrant groups.

However, they do not allow for the possibility that payoffs for different characteristics are different across immigrant groups. Results from Table 4, for example, do not allow us to see if Nordic women have a very different payoff to schooling as compared to women from the Middle East. Further, results at this level do not allow us to measure the impact of the co-ethnic population because all immigrant groups are rolled into the "log of immigrant population” variable. Table 6 resolves this situation by providing selected coefficients from a total of eighteen separate regressions-a separate regression for each place of birth by gender group. The dependent variable remains employment status and independent variables include all the variables from Table 3 . Thus we allow each of the coefficients to vary independently for each place of birth group (equivalent to results from Table 3, but where each characteristic is interacted with place of birth).

Regression results shown in Table 6 include one additional independent variable. For each respondent we have added the log of the number of immigrants from the same 
group who live in their city. Thus, for example, in the case of a Nordic immigrant from Malmo, “the Log of immigrant population” variable corresponds to the log of the number of Nordic immigrants living in the Malmo.

As can be seen in Table 6, with the exception of immigrants from Nordic countries and North America, a larger immigrant population is correlated with lower probabilities of employment (ranging from -0.01 to -0.05 for every log unit increase in a municipality’s immigrant population). The coefficients for the log of the co-immigrant group size, however, move in the opposite direction. With the exception of women from Nordic countries, the coefficients are positive and range from 0.01 to 0.03 for every log unit increase in the municipality’s co-immigrant population. The impact of the coimmigrant population is often stronger for men than for women. For example, for immigrants from the Middle East or Asia, the coefficient for the log of the co-immigrant population is 0.01 for women and 0.02 for men. This suggests that having a large coethnic population may be effective in increasing employment prospects for its members. With the exception of immigrants from Nordic countries and men from the EU 25, the impact of acquiring citizenship is uniformly positive and strong for all immigrant groups, ranging from 0.19 to 0.46 for women and 0.15 to 0.20 for men. The highest impact of citizenship is found for immigrants from Europe outside the EU and the Nordic countries (0.46 for women and 0.20 for men). We note that the effect is often stronger for women than it is for men. For example, for women from Africa, the coefficient for citizenship is 0.27 , while for men it is 0.17 . 


\section{Conclusion}

The latter half of the twentieth century saw a liberalization in immigrant intake and citizenship acquisition regulations in many immigrant receiving countries. More recently, countries such as Denmark, the Netherlands, the UK, Canada, and the USA have tightened up citizenship and immigrant intake regulations and have witnessed declines in the employment probabilities for immigrants. In contrast, Sweden has continued to liberalize citizenship acquisition regulations, most recently recognizing dual citizenship (2001), while at the same time seeing declining employment prospects for immigrants. Several scholars have argued that there is a link between citizenship acquisition and employment status (i.e., Devoretz and Pivenko [2008] in regards to Canada; Akbari [2008] in studies of the US; and Steinhardt [2008] and Hayfron [2008] in European studies). These studies, however, are hampered by their inability to distinguish the effect of citizenship from the effect of integration processes (i.e., they cannot say whether the measured impact is a product of citizenship or some correlate of citizenship such as better integration).

In this paper, we used instrumental variable regression to examine the "clean” impact of citizenship acquisition and the size of the co-immigrant population on the probability of being employed. In contrast to Scott (2008), we find that citizenship acquisition has a positive impact for a number of immigrant groups. This is particularly the case for non-EU/non-North American immigrants. In terms of intake class, refugees appear to experience substantial gains from citizenship acquisition (this is not, however, the case for immigrants entering as family class). 
The size of the co-ethnic population has a positive impact for many immigrant groups-as the co-ethnic population increases, the probability of being employed also increases. It appears to be particularly important for immigrants from Asia and Africa, immigrant groups who also face the lowest employment prospects. For these immigrants, the co-immigrant population may serve as an employer of last resort, buffering the impact of possible discrimination by the majority population. It could also be an indicator of a lack of linguistic integration, which effectively locks immigrants out of the majority labour force (see, for example, Pendakur and Pendakur 2002).

So, in a country where the barriers to non-citizens are relatively few (i.e., noncitizens have access to most of the jobs and most of the rights of citizens, both social and legal), why might citizenship help in employment prospects? Spence (1973) argues that observable characteristics act as signals to employers about the potential risk of hiring new employees. Within this context, citizenship may act as a signal to employers about an immigrant's commitment to remaining in Sweden. Hiring a citizen thus reduces transaction and risk costs to employers because they can be more certain that the new employee will remain in the position.

Looking at citizenship and employment from a policy perspective, what are the implications of tightening up citizenship acquisition requirements? Our contention is that given citizenship’s apparent link to improved employment prospects, tightening up citizenship regulations may result in decreased employment opportunities for immigrants in receiving countries. This means, in turn, that stricter citizenship regulations could have the effect of actually increasing social welfare costs - an effect neither intended nor desirable. 


\section{References}

Akbari, A. H. 2008. Immigrant naturalization and its impacts on immigrant labour market performance and treasury. In The economics of citizenship, ed. Pieter Bevelander and Don J. DeVoretz. MIM/Malmö University. Malmö: Holmbergs.

Bevelander, P. 2000. Immigrant employment integration and structural change in Sweden, 1970-1995. Sweden: Almqvist \& Wiksell International. [AUTHOR: provide city of publication instead of country, if available.]

- 2009. The immigration and integration experience: The case of Sweden. In Immigration worldwide, ed. Uma A. Segal, Nazneen S. Mayadas, and Doreen Elliott. Oxford: Oxford University Press.

Bevelander, P. and D. DeVoretz, eds. 2008. The economics of citizenship. MIM/Malmö University. Malmö: Holmbergs.

Bevelander, P. and J. Veenman. 2006. Naturalization and immigrants' employment integration in the Netherlands. Journal of International Migration and Integration 7(3).

- 2008. Naturalisation and socioeconomic integration: The case of the Netherlands. RIIM and IZA discussion paper. In The economics of citizenship, ed. Pieter Bevelander and Don J. DeVoretz. MIM/Malmö University. Malmö: Holmbergs.

Bonacich, E. and J. Model. 1980. The economic basic of ethnic solidarity. Berkeley: University of California Press.

Bratsberg, B., J. F. Ragan and Z. M. Nasir. 2002. The effect of naturalization on wage growth: A panel study of young male immigrants. Journal of Labor Economics 20: 568-97.

Breton, R. 1974. Ethnic stratification viewed from three theoretical perspectives. In Social stratification: Canada, 2nd edition, ed. J. E. Curtis and W. Scott. Toronto: Prentice-Hall.

Castles, S. and M. J. Miller. 2003. The age of migration: International population movements in the modern world. 3rd edition. Basingstoke: Palgrave.

Chiswick, B. 1978. The effect of Americanization on the earnings of foreign-born men. The Journal of Political Economy 86: 897-921.

DeVoretz, D. J. and S. Pivnenko. 2006. The economic causes and consequences of Canadian citizenship. Journal of International Migration and Integration 6: 435-68. 
_ 2008. The economic determinants and consequences of Canadian citizenship ascension. In The economics of citizenship, ed. Pieter Bevelander and Don J. DeVoretz. MIM/Malmö University. Malmö: Holmbergs.

Hayfron J. E. 2008. The economics of Norwegian citizenship. In The economics of citizenship, ed. Pieter Bevelander and Don J. DeVoretz. MIM/Malmö University. Malmö: Holmbergs.

Kogan, I. 2003. Ex-Yugoslavs in the Austrian and Swedish labor markets: The significance of period of migration and the effect of citizenship acquisition. Journal of Ethnic and Migration Studies 29: 595-622.

Light, I. 1997. Immigrant and ethnic enterprise in North America. Ethnic and Racial Studies 7: 195-216.

Lundh, C. and R. Ohlsson. 1999. Från arbetskraftimport till flyktinginvandring. Andra reviderade upplagan. Stockholm: SNS Förlag.

Mazzolari, F. 2007. Dual citizenship rights: Do they make more and better citizens? IZA Discussion Paper No. 3008, Institute for the Study of Labor, Bonn.

Ohlsson, R. 1975. Invandrarna på arbetsmarknaden. Lund: Ekonomisk-historiska föreningen.

Pendakur, K. and R. Pendakur. 2002. Language knowledge as human capital and ethnicity. International Migration Review 36(1): 147-77.

Scott, K. 2008. The economics of citizenship: Is there a naturalization effect? In The economics of citizenship, ed. Pieter Bevelander and Don J. DeVoretz. MIM/Malmö University. Malmö: Holmbergs.

Spence, M. 1973. Job market signalling. The Quarterly Journal of Economics 87(3): 35574.

Steinhardt, M. F. 2008. Does citizenship matter? The economic impact of naturalizations in Germany. Centro Studi Luca D’Agliano Development Studies Working Paper No. 266. Centro Studi Luca D’Agliano, Milan/Torino.

Wadensjö, E. 1973. Immigration och samhällsekonomi. Lund.

Wilson, K. and A. Portes. 1980. Immigrant enclaves: An analysis of the labor market experiences of Cubans in Miami. American Journal of Sociology 86: 295-319. 
Table 1

Citizenship acquisition in Sweden

by country of birth, 2006

\begin{tabular}{|lr|}
\hline Country of birth & Percent \\
\hline Lebanon & 96 \\
Syria & 96 \\
Rumania & 93 \\
Iran & 93 \\
Iraq & 93 \\
Ethiopia & 92 \\
Yugoslavia & 91 \\
Hungary & 91 \\
Bosnia-Herzegovina & 87 \\
Turkey & 87 \\
Poland & 81 \\
Greece & 78 \\
Chile & 76 \\
Somalia & 75 \\
Germany & 70 \\
Finland & 68 \\
Denmark & 57 \\
Italy & 54 \\
Norway & 48 \\
The Netherlands & 45 \\
\hline
\end{tabular}


Table 2

\% Employed by Group, Sex and Citizenship

\begin{tabular}{|l|cc|cc|}
\hline \multirow{2}{*}{ Place of Birth } & \multicolumn{2}{|c|}{ Females } & \multicolumn{2}{c|}{ Males } \\
\cline { 2 - 5 } Swedish & Non-citizens & Citizens & Non-citizens & Citizens \\
Nordic & & $81 \%$ & & $81 \%$ \\
EU25 & $68 \%$ & $71 \%$ & $60 \%$ & $74 \%$ \\
Rest of Europe & $53 \%$ & $67 \%$ & $63 \%$ & $69 \%$ \\
N. America & $37 \%$ & $62 \%$ & $47 \%$ & $71 \%$ \\
Latin America & $44 \%$ & $72 \%$ & $54 \%$ & $75 \%$ \\
Africa & $44 \%$ & $68 \%$ & $57 \%$ & $73 \%$ \\
Middle East & $21 \%$ & $59 \%$ & $32 \%$ & $64 \%$ \\
S. Asia & $13 \%$ & $48 \%$ & $26 \%$ & $61 \%$ \\
E. Asia & $25 \%$ & $61 \%$ & $31 \%$ & $68 \%$ \\
\end{tabular}


Table 3: Results from 2 OLS regressions on being employed.

\begin{tabular}{|c|c|c|c|c|c|}
\hline & & & obust & & $\begin{array}{l}\text { S } \\
\text { Robust }\end{array}$ \\
\hline variable & & Coef. & S.E. sig & Coef. & S.E. sig \\
\hline Model Summary & Observations & 345,494 & & 323,991 & \\
\hline & $\mathrm{R} 2$ & 0.13 & & 0.11 & \\
\hline City Characteristics & Log of city size & -0.03 & $0.00 * \star \star$ & -0.03 & $0.00 * \star \star$ \\
\hline & Log of immigrant pop & 0.02 & $0.00 * * *$ & 0.02 & $0.00 * \star \star$ \\
\hline & $\%$ employed in city & 1.02 & $0.03 * \star \star$ & 1.45 & $0.04 \star \star \star$ \\
\hline Age (25-34) & $35-44$ & 0.05 & $0.00 * * *$ & -0.02 & $0.00 * \star \star$ \\
\hline & $45-54$ & 0.01 & $0.00 * * *$ & -0.08 & $0.00 * \star \star$ \\
\hline & $55-64$ & -0.14 & $0.00 * * \star$ & -0.22 & $0.00 \star \star \star$ \\
\hline Marital status (single) & Married & 0.01 & $0.00 * * *$ & 0.07 & $0.00 * \star \star$ \\
\hline & Divorced/Separated & -0.02 & $0.00 * * *$ & 0.00 & 0.00 \\
\hline & Widowed & -0.04 & $0.01 * \star \star$ & -0.01 & 0.01 \\
\hline & Partner is Swedish & 0.07 & $0.00 * * \star$ & 0.07 & $0.00 * * *$ \\
\hline Presence of children (none) & 1 child & 0.04 & $0.00 * \star \star$ & 0.10 & $0.00 * * *$ \\
\hline & 2 children & 0.04 & $0.00 * * *$ & 0.13 & $0.00 * * *$ \\
\hline & $3+$ children & -0.04 & $0.00 * * *$ & 0.07 & $0.00 * \star \star$ \\
\hline Schooling (< secondary) & Lower secondary & 0.15 & $0.01 * * *$ & 0.10 & $0.01 * * \star$ \\
\hline & Upper secondary & 0.22 & $0.01 * \star \star$ & 0.18 & $0.01 * \star \star$ \\
\hline & Lower university & 0.20 & $0.01 * * *$ & 0.15 & $0.01 * \star \star$ \\
\hline & Upper university & 0.31 & $0.01 * * *$ & 0.21 & $0.01 * \star \star$ \\
\hline & Last level outside Sweden & 0.01 & 0.01 & 0.05 & 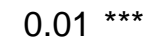 \\
\hline & Lower secondary & 0.01 & 0.01 * & -0.02 & $0.01 * \star \star$ \\
\hline & Upper secondary & -0.03 & $0.01 * * *$ & -0.05 & $0.01 * * *$ \\
\hline & Lower university & -0.01 & 0.01 & -0.02 & $0.01 * \star \star$ \\
\hline & Upper university & -0.03 & $0.01 * \star \star$ & -0.02 & $0.01 * * \star$ \\
\hline Country of birth (Nordic) & EU not Nordic & -0.08 & $0.00 * * *$ & -0.02 & $0.00 * \star \star$ \\
\hline & Rest of Europe & -0.08 & $0.00 * * *$ & -0.05 & $0.00 * * \star$ \\
\hline & N. America & -0.10 & $0.01 * * *$ & -0.06 & $0.01 \star \star \star$ \\
\hline & Latin Amer & -0.07 & $0.00 * * *$ & -0.02 & $0.00 * * *$ \\
\hline & Africa & -0.12 & $0.00 * * \star$ & -0.13 & $0.00 \star \star \star$ \\
\hline & Middle East & -0.23 & $0.00 * \star *$ & -0.16 & $0.00 * \star \star$ \\
\hline & S. Asia & -0.16 & $0.00 * * *$ & -0.12 & $0.00 * \star \star$ \\
\hline & E. Asia & -0.04 & $0.00 * \star \star$ & -0.07 & $0.01 \star \star \star$ \\
\hline Migration characteristics & Years since migrating & 0.018 & $0.00 * \star *$ & 0.012 & $0.00 * * *$ \\
\hline & Yrs since mig sq & 0.00 & $0.00 * * *$ & 0.00 & $0.00 * * *$ \\
\hline & Citizenship (Swedish) & 0.06 & $0.00 * \star \star$ & 0.08 & $0.00 * \star \star$ \\
\hline
\end{tabular}

Significance:

*: $0.1 ; * \star$ : $0.05 ;{ }^{\star \star \star}: 0.01$ 
Table 4: Results from 2 Instrumental Variable (IV) regressions on being employed.

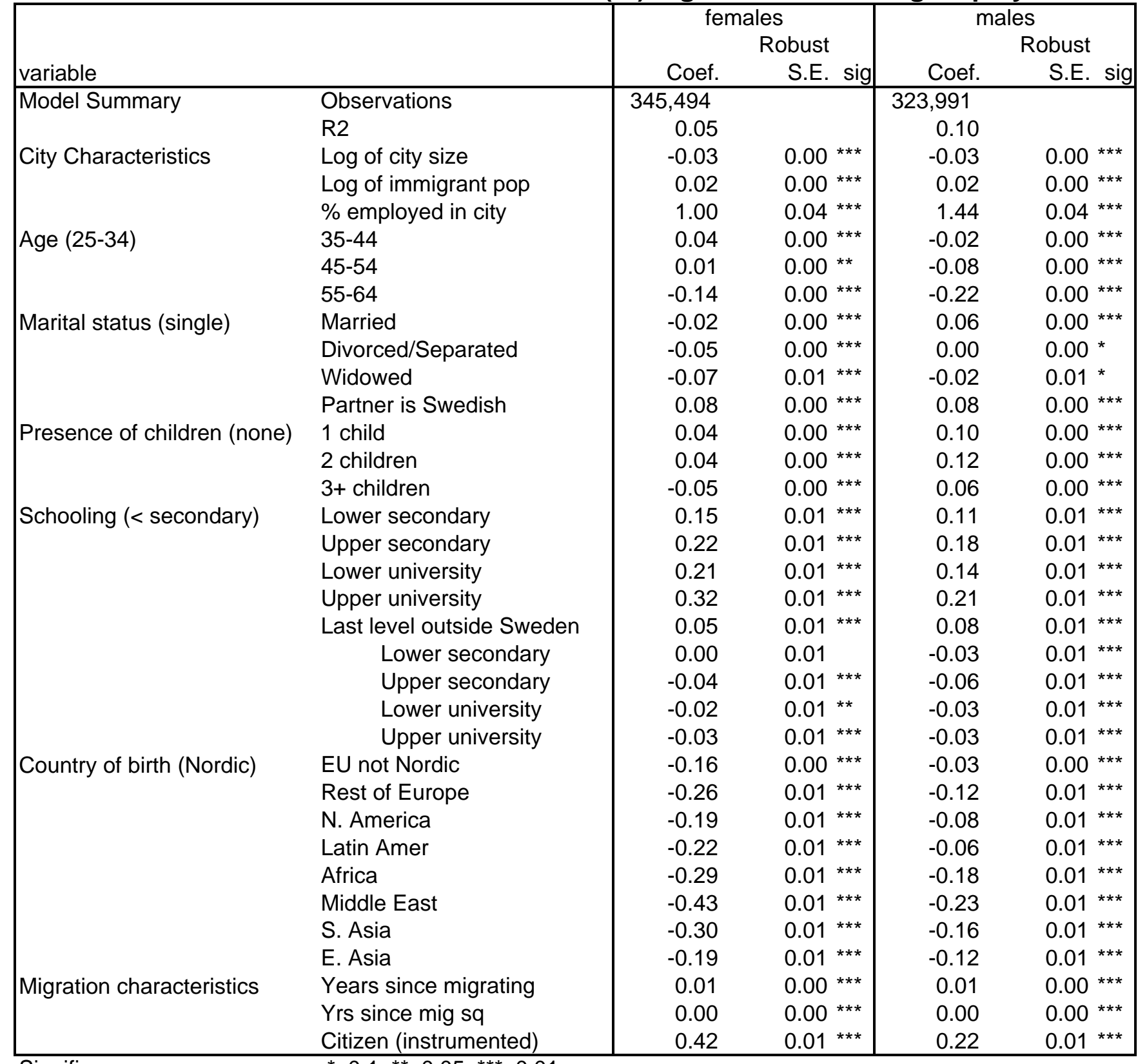

Significance:

*: $0.1 ;{ }^{* *}: 0.05 ;$ ***: 0.01 
Table 5: Partial results from 6 Instrumental Variable (IV) regressions on being employed

\begin{tabular}{|c|c|c|c|c|c|c|}
\hline & & & males & & nales & \\
\hline group & variable & Coef. & Robust S.E. sig & Coef. & Robust S.E. & sig \\
\hline all immigrants & Observations & 345,494 & & 323,991 & & \\
\hline & R2 & 0.05 & & 0.10 & & \\
\hline & Log of city size & -0.03 & $0.00 * \star \star$ & -0.03 & 0.00 & 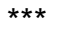 \\
\hline & Log of immigrant pop & 0.02 & $0.00 * \star *$ & 0.02 & 0.00 & *** \\
\hline & $\%$ employed in city & 1.00 & $0.04 * \star \star$ & 1.44 & 0.04 & $\star \star \star ~$ \\
\hline & Citizen (instrumented) & 0.42 & $0.01 * \star *$ & 0.22 & 0.01 & *** \\
\hline Family & Observations & 99,335 & & 58,133 & & \\
\hline & R2 & 0.14 & & 0.02 & & \\
\hline & Log of city size & -0.04 & $0.00 * * \star$ & -0.05 & 0.01 & *** \\
\hline & Log of immigrant pop & 0.03 & $0.00 * \star *$ & 0.04 & 0.00 & *** \\
\hline & \% employed in city & 1.20 & $0.07 \star \star \star$ & 1.56 & 0.10 & 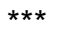 \\
\hline & Citizen (instrumented) & -0.02 & 0.04 & -0.20 & 0.06 & *** \\
\hline Refugees & Observations & 59,009 & & 84,700 & & \\
\hline & R2 & 0.17 & & 0.14 & & \\
\hline & Log of city size & -0.02 & $0.01 * \star \star$ & -0.05 & 0.01 & 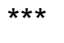 \\
\hline & Log of immigrant pop & 0.01 & $0.00 *$ & 0.03 & 0.00 & 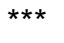 \\
\hline & $\%$ employed in city & 0.83 & $0.08 * \star \star$ & 1.24 & 0.07 & 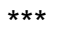 \\
\hline & Citizen (instrumented) & 0.16 & $0.03 * * *$ & 0.15 & 0.03 & *** \\
\hline Note: & $\begin{array}{l}\text { Other variables include } \\
\text { spouse, presence of ch } \\
\text { schooling }\end{array}$ & $\begin{array}{l}\text { d in the regre } \\
\text { ildren, schoo }\end{array}$ & $\begin{array}{l}\text { ion are: age, m } \\
g, \text { and schoolin }\end{array}$ & $\begin{array}{l}\text { tal status, pla } \\
\text { nteracted with }\end{array}$ & $\begin{array}{l}\text { ce of birth of } \\
\text { place of }\end{array}$ & \\
\hline Significance: & $*: 0.1 ; * *: 0.05 ; * * *: 0.0$ & & & & & \\
\hline
\end{tabular}


Table 6: Partial results from 18 Instrumental Variable (IV) regressions on being employed

\begin{tabular}{|c|c|c|c|c|c|c|c|}
\hline & & & males & & & nales & \\
\hline group & variable & Coef. & Robust S.E. & sig & Coef. & Robust S.E. & sig \\
\hline Nordic & Observations & 88,082 & & & 70,435 & & \\
\hline & $\mathrm{R} 2$ & 0.00 & & & 0.00 & & \\
\hline & Log of city size & 0.007 & 0.013 & & 0.033 & 0.010 & $\star \star * *$ \\
\hline & Log of immigrant pop & -0.035 & 0.012 & 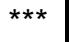 & -0.048 & 0.010 & *** \\
\hline & $\%$ employed in city & 1.836 & 0.214 & $\star \star \star *$ & 2.071 & 0.153 & *** \\
\hline & In group size & -0.003 & 0.004 & & 0.017 & 0.003 & 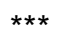 \\
\hline & Citizen (instrumented) & -2.899 & 0.319 & $\star \star \star$ & -1.923 & 0.234 & $\star \star \star *$ \\
\hline EU 25 & Observations & 58,211 & & & 55,695 & & \\
\hline & $\mathrm{R} 2$ & 0.00 & & & 0.04 & & \\
\hline & Log of city size & 0.012 & 0.007 & & -0.017 & 0.007 & $\star \star$ \\
\hline & Log of immigrant pop & -0.026 & 0.006 & $\star \star \star \star$ & -0.003 & 0.006 & \\
\hline & $\%$ employed in city & 1.195 & 0.095 & $\star \star \star$ & 1.079 & 0.097 & $\star * \star$ \\
\hline & In group size & 0.011 & 0.002 & $\star \star \star$ & 0.006 & 0.002 & 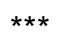 \\
\hline & Citizen (instrumented) & 0.505 & 0.043 & $\star \star \star *$ & -0.271 & 0.071 & *** \\
\hline Rest of Europe & Observations & 57,777 & & & 51,963 & & \\
\hline & $\mathrm{R} 2$ & 0.08 & & & 0.14 & & \\
\hline & Log of city size & -0.008 & 0.007 & & -0.003 & 0.007 & \\
\hline & Log of immigrant pop & -0.010 & 0.006 & & -0.018 & 0.006 & $\star * *$ \\
\hline & $\%$ employed in city & 0.525 & 0.079 & $\star \star \star$ & 0.985 & 0.074 & $\star \star \star *$ \\
\hline & In group size & 0.005 & 0.002 & ** & 0.007 & 0.002 & *** \\
\hline & Citizen (instrumented) & 0.456 & 0.021 & $\star \star \star$ & 0.198 & 0.022 & *** \\
\hline N. America & Observations & 7,739 & & & 9,218 & & \\
\hline & R2 & 0.10 & & & 0.12 & & \\
\hline & Log of city size & -0.001 & 0.017 & & -0.009 & 0.015 & \\
\hline & Log of immigrant pop & -0.005 & 0.015 & & 0.003 & 0.013 & \\
\hline & $\%$ employed in city & 0.613 & 0.272 & ** & 1.040 & 0.251 & *** \\
\hline & In group size & 0.011 & 0.004 & $\star \star \star$ & 0.008 & 0.004 & $\star \star$ \\
\hline & Citizen (instrumented) & 0.275 & 0.081 & $\star \star \star$ & 0.154 & 0.069 & $\star \star$ \\
\hline Latin Amer. & Observations & 18,723 & & & 17,713 & & \\
\hline & $\mathrm{R} 2$ & 0.01 & & & 0.07 & & \\
\hline & Log of city size & -0.012 & 0.012 & & -0.029 & 0.011 & $\star \star$ \\
\hline & Log of immigrant pop & -0.002 & 0.011 & & 0.015 & 0.010 & \\
\hline & $\%$ employed in city & 0.954 & 0.190 & $\star \star \star$ & 1.119 & 0.178 & 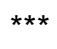 \\
\hline & In group size & 0.019 & 0.003 & $\star \star \star *$ & 0.008 & 0.003 & *** \\
\hline & Citizen (instrumented) & 0.434 & 0.067 & 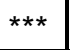 & 0.067 & 0.087 & \\
\hline Africa & Observations & 18,260 & & & 23,271 & & \\
\hline & $\mathrm{R} 2$ & 0.12 & & & 0.11 & & \\
\hline & Log of city size & 0.031 & 0.014 & ** & 0.011 & 0.012 & \\
\hline & Log of immigrant pop & -0.055 & 0.013 & $\star \star \star$ & -0.033 & 0.011 & $\star \star \star *$ \\
\hline & $\%$ employed in city & 1.074 & 0.222 & $\star \star \star$ & 1.123 & 0.200 & $\star \star \star *$ \\
\hline & In group size & 0.027 & 0.003 & $\star \star \star$ & 0.023 & 0.003 & $\star \star \star *$ \\
\hline & Citizen (instrumented) & 0.269 & 0.048 & $\star \star \star$ & 0.173 & 0.069 & ** \\
\hline
\end{tabular}


Table 6: Partial results from 18 Instrumental Variable (IV) regressions on being employed

\begin{tabular}{|c|c|c|c|c|c|}
\hline & & & males & & nales \\
\hline group & variable & Coef. & Robust S.E. sig & Coef. & Robust S.E. sig \\
\hline Middle East & Observations & 58,554 & & 72,940 & \\
\hline & R2 & 0.16 & & 0.11 & \\
\hline & Log of city size & 0.02 & $0.01 * \star *$ & -0.02 & $0.01 * * *$ \\
\hline & Log of immigrant pop & -0.040 & $0.007 * * *$ & -0.008 & 0.006 \\
\hline & $\%$ employed in city & 0.920 & $0.111 * \star \star$ & 1.358 & $0.102 * \star *$ \\
\hline & In group size & 0.022 & $0.002 * * *$ & 0.016 & $0.002 * * \star$ \\
\hline & Citizen (instrumented) & 0.142 & $0.017 * \star *$ & 0.137 & $0.022 * \star \star *$ \\
\hline S. Asia & Observations & 15,426 & & 14,578 & \\
\hline & $\mathrm{R} 2$ & 0.07 & & 0.09 & \\
\hline & Log of city size & 0.006 & 0.013 & -0.037 & $0.013 * * *$ \\
\hline & Log of immigrant pop & -0.016 & 0.011 & 0.008 & 0.012 \\
\hline & $\%$ employed in city & 1.574 & $0.195 * \star \star$ & 1.180 & $0.199 * \star \star$ \\
\hline & In group size & 0.018 & $0.003 * * *$ & 0.020 & $0.003 * * *$ \\
\hline & Citizen (instrumented) & 0.446 & 0.071 *** & 0.289 & $0.071 * \star *$ \\
\hline E. Asia & Observations & 22,721 & & 8,147 & \\
\hline & R2 & 0.00 & & 0.11 & \\
\hline & Log of city size & 0.011 & 0.010 & -0.042 & $0.017 * \star$ \\
\hline & Log of immigrant pop & -0.021 & $0.009 \star \star$ & 0.029 & 0.015 * \\
\hline & $\%$ employed in city & 1.453 & $0.150 * \star *$ & 1.482 & $0.218 * * *$ \\
\hline & In group size & 0.025 & $0.003 * * *$ & 0.012 & $0.005 * *$ \\
\hline & Citizen (instrumented) & 0.479 & $0.056 * \star *$ & 0.175 & 0.112 \\
\hline
\end{tabular}

Note: $\quad$ Other variables included in the regression are: age, marital status, place of birth of spouse, presence of children, schooling, and schooling interacted with place of schooling

Significance: $\quad$ *: $0.1 ; * *: 0.05 ; * \star *: 0.01$ 


\section{Appendix Table 1: Test of Model Showing $t$ test}

\begin{tabular}{|c|c|c|c|c|c|}
\hline & \multicolumn{4}{|l|}{ Instrument } \\
\hline & & \multicolumn{2}{|c|}{$\begin{array}{l}\text { Eligible for Citizenship and } \\
\text { Years since Eligible }\end{array}$} & \multicolumn{2}{|c|}{ Eligible for citizenship only } \\
\hline group & variable & females & males & females & males \\
\hline \multicolumn{2}{|c|}{ All immigrants Eligible for citizenship } & 107.92 & 91.15 & 115.67 & 88.22 \\
\hline & Years since eligible & 8.9 & 33.36 & & \\
\hline \multirow[t]{2}{*}{ Nordic } & Eligible for citizenship & -4.87 & -4.01 & -9.65 & -9.47 \\
\hline & Years since eligible & 4.53 & 5.67 & & \\
\hline \multirow[t]{2}{*}{ EU 25} & Eligible for citizenship & 26.66 & 16.79 & 27.53 & 11.05 \\
\hline & Years since eligible & 3.75 & 16.17 & & \\
\hline \multicolumn{2}{|c|}{ Rest of Europє Eligible for citizenship } & 54.95 & 47.26 & 53.6 & 46.72 \\
\hline & Years since eligible & 16.03 & 14.67 & & \\
\hline \multirow[t]{2}{*}{ N. America } & Eligible for citizenship & 12.4 & 13.87 & 11.46 & 11.44 \\
\hline & Years since eligible & 5.57 & 9.02 & & \\
\hline \multirow[t]{2}{*}{ Latin Amer. } & Eligible for citizenship & 14.45 & 8.86 & 16.07 & 10.21 \\
\hline & Years since eligible & -4.26 & -5.45 & & \\
\hline \multirow[t]{2}{*}{ Africa } & Eligible for citizenship & 15.96 & 13.3 & 20.17 & 14.86 \\
\hline & Years since eligible & -9.67 & -2.43 & & \\
\hline \multirow[t]{2}{*}{ Middle East } & Eligible for citizenship & 55.6 & 49.19 & 62.31 & 50.21 \\
\hline & Years since eligible & -18.04 & -4.46 & & \\
\hline \multirow[t]{2}{*}{ S. Asia } & Eligible for citizenship & 12.38 & 14.55 & 14.77 & 15.05 \\
\hline & Years since eligible & -2.62 & 1.22 & & \\
\hline \multirow[t]{2}{*}{ E. Asia } & Eligible for citizenship & 12.72 & 9.99 & 19.04 & 9.68 \\
\hline & Years since eligible & -7.82 & 2.58 & & \\
\hline \multirow[t]{2}{*}{ Refugees } & Eligible for citizenship & 26.43 & 27.49 & 30.82 & 0 \\
\hline & Years since eligible & -1.45 & -5.92 & & \\
\hline \multirow[t]{2}{*}{ Family } & Eligible for citizenship & 27.71 & 17.69 & 27.02 & 18.19 \\
\hline & Years since eligible & -9.25 & 2.26 & & \\
\hline
\end{tabular}

